\title{
THE ECO-EFFICIENCY AND SUSTAIBLE NATIONAL PROJECTS IN EGYPT
}

\author{
KHALED EL-SAKTY \\ Head of Transport Logistics Department \& Vice Dean of College of International Transport and Logistics, \\ Arab Academy for Science and Technology and Maritime Transport, Cairo, Egypt., \\ Tel: +2 0100833 4341, E-mails: khaled.sakty@aast.edu
}

\begin{abstract}
As a national mega project, the Suez Canal Area Development Project has logistically imposed two main questions. First: how can the project spot an ideal solution for balancing the business and environmental concerns? Second: how can the project enhance the trade-off between these two dimensions? In order to answer these two questions, the efficient frontier between the profitability and the environmental impact needs to be investigated. In this paper, the Strategic Thinking Approach will be discussed for improving the Ecoefficiency. The main purpose of this paper is to discuss the eco-efficiency solution and to identify the appropriate way for measuring the environmental performance in such a project.
\end{abstract}

Keywords - Eco-efficiency, Suez Canal Area Development Project , Eco-efficiency Analysis.

\section{INTRODUCTION}

In a supply chain context, suppliers, customers and governments have recently increased their attention towards the balance between the profitability of establishing mega national projects on one hand and the environmental and societal impacts on the other. Hence, governments have changed the 'end-of-pipe' laws to more comprehensive one, worldwide. Here, one question arises: which trade-offs would be counted for between the environmental impacts of an activity project such as the Suez Canal Area Development Project, known as "New Suez Canal Project" and the associated costs of the project?. In other words, what are the best solutions balancing between the ecological and economic concerns of such a project?

These questions lead to a concept of eco-efficiency as displayed in Figure 1. The axes represent the economic value and the environmental quality of economic activity expected from establishing a mega project. The eco-efficiency curve provides either decreasing the environmental pressure without decreasing the economic value added, or increasing economic value without restricting environmental quality. In both cases, the right direction is to move to the efficient frontier. As each point on the efficient frontier is Pareto optimal, it is up to the decision makers to decide which improvement path is preferred. In most cases, increasing environmental quality without losing economic value means moving to the right direction when establishing new projects. In other words, increasing economic value without losing environmental quality means moving up (Neto et. al., 2007).

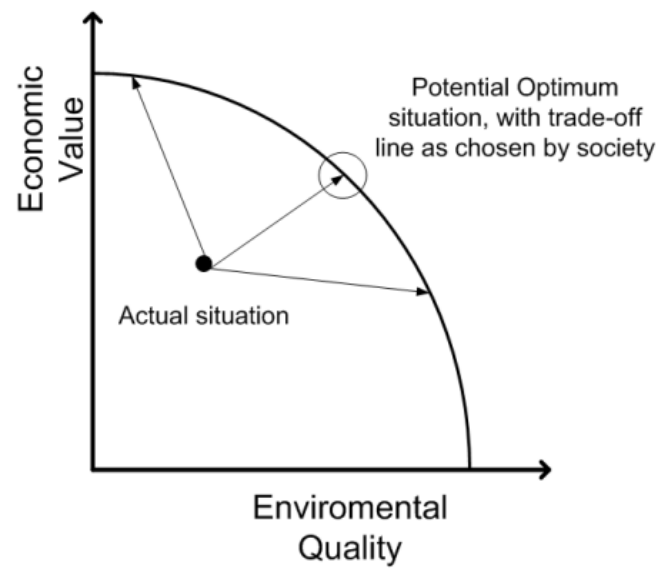

Fig .1. Eco-efficiency of Mega Project Source: Huppes and Ishikawa, 2005

According to a management philosophy, the ecoefficiency aims to combine business excellence with business excellence that can support sustainable development. Concerning the strategic framework of economic and social Development Plan in Egypt 2022, the economic value can be realized when the investment policies (including financial, monetary and commercial policies) are directed towards enhancing demand on work in national mega projects. In addition, institutional and legislative reforms should be added to the policies, focusing on developing unorganized labor market. Environmentally, the environment should support small and micro projects as well as young 
businessmen to improve the chances of having land, loans, and instructional services. In many projects, the quality of environment is affected due to unsustainable use of natural resources, shortage in water resources, and many environmental problems related to different activities in agriculture, industry drinking water, sanitary sewage sectors and other problems.

According to a United Nation Program definition of environment as "green economy", we understand that environment could be seen as a tool to help modify unsustainable consumption and production attitude resulting in pollution. It can also help modify the overuse of natural resources, especially energy sources and its emissions. Accordingly, the national mega projects in Egypt such as the Suez Canal Area Development Project should consider this new attitude that leads to more efficient and diverse economy in terms of usage and production of the resources which preserve environment and create proper job opportunities. Such a project must encourage sustainable trade operations in order to limit the rate of poverty and achieve social justice.

Moreover, the objectives of the Suez Canal Area Development Project should include the following: creating extended job opportunities, generating investment projects, increasing exportation scale, promoting world trade activities, ensuring long-term economic growth by integrating the existing activities and attracting new foreign investment, using the available resources to find out best practices in the field of sustainable development, and upgrading the efficiency of Egyptian laborers to meet the international advanced labor standards. Consequently, the potential optimum can be attained by reviewing the economic value together with the quality of the environment as displayed in Figure 1. In the next section, the importance of eco-efficiency in improving the performance of any logistic system will be discussed.

\section{RESEARCH PROBLEM}

In national mega projects, a management philosophy often aims at encouraging business to develop and commercialize products with environmental improvements that would yield economic benefits. There are two challenges facing managers in this case. First, they need to know what the potential drivers that affect the environmental performance are. Second, they need to have tools that can be applied by them to achieve comprehensive environmental and economic benefits for such projects. This paper is trying to seek out a solution for these two problems. The paper is limited to identify the appropriate methodology for managing an environmental performance in national projects.

\section{METHODOLOGY}

Exploratory approach was conducted in this paper to help understand the research problem and provide significant insights into a given situation. It relies on secondary research such as reviewing available literature, qualitative approach and projective methods. This approach helps build strength around the linkage between process elements, metrics, best practices and opportunities for eco-efficiency in logistics cluster. In this research, the exploratory approach helps to understand the scientific thinking process for improving the Eco-efficiency in such a project.

\section{ECO-EFFICIENCY AND BUSINESS CASE}

Eco-efficiency includes creating economic value and reducing environmental impact and resource use at the same time. This leads to a more significant value to be added to any project. Five aspects of ecoefficiency have been identified that make it an indispensable strategic element in business project. These aspects are:

- Eco-innovation

- Optimized processes

- Networks/virtual organizations

- New services

- Waste recycling

Any project includes a set of activities, where ecoefficiency can be implemented along the entire value chain of a product or service. Implementing the ecoefficiency can be achieved through seven key approaches:

- Reduce material intensity

- Energy intensity minimized 
- Dispersion of toxic substances is reduced

- Undertake recycling

- Capitalize on use of renewables

- Extend product durability

- Service intensity is increased.

\section{ECO-EFFICIENCY AND LOGISTICS NETWORK}

Increasing importance of sustainable development has lead eco-efficiency to find a specific position in literature. Eco-efficiency means producing goods and delivering services by using lower energy and raw material which together result in lower amount of waste, pollution and cost. Hence, eco-efficiency considers two aspects: economic and environmental.

As a methodology, using the eco-efficiency concept in assessing the trade-off in logistics networks has recently received attention (Neto et al., 2008). Determining the eco-efficient frontier regarding business and the environment for the design of sustainable logistics networks in Suez region requires using such measures. Three measures can be used to describe the eco-efficiency of any project (Krikke et al., 2003). These measures are cost, energy/resource usage and waste. On the other hand, consumers and legislators have pushed companies to re-design their logistics networks in order to mitigate negative environmental impacts. The objective in the design of logistics networks has changed, therefore, from cost minimization only, to cost and environmental impact minimization.

In general, a logistics network has a number of players that influence business costs and environment impact. Suppliers, manufactures, consumers, operators, third parties operating in testing, refurbishing, recycling and energy producers for the end-of-life products are the main players (Neto et al., 2008). These players affect both businesses and the environment. These activities are related to manufacturing, transportation, usage and end-of-life products' and destination as shown in Figure 2. The decisions regarding these activities will, therefore, determine the network costs and environmental impact. These decisions are strategic (e.g. location of proposed projects in the New Suez Canal Area Development Project), tactical (e.g. the destination of end-of-life products), and operational (e.g. the choice of suppliers, third parties, investors, etc.).

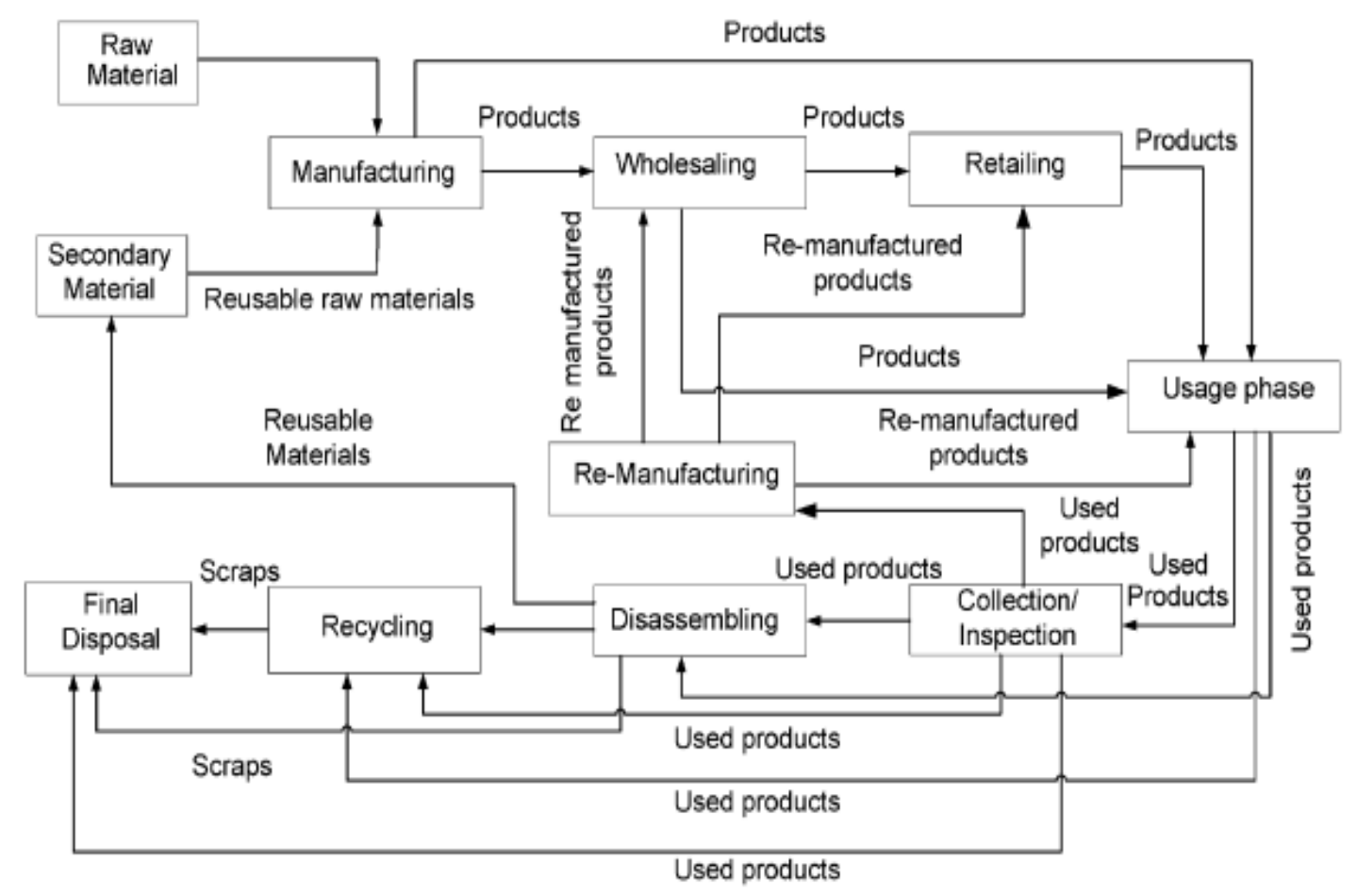

Fig .2. Framework for a sustainable Logistics Network Source: Neto et al., 2008. 
Hence, it is obvious that choosing the right activities in demonstrating definite logistics nets is fundamental. In the available Literature, logistics network design is commonly divided in two approaches: minimizing costs (or maximizing profits) and minimizing environmental impact. However, there is little done integrating these two formulations (BloemhofRuwaard et al., 2004). In other words, there is a lack of integration or capturing the trade-offs between the logistics network costs and its respective environmental footprint. Thus, the eco-efficiency is applied in this research for this purpose.

\section{ECO-EFFICIENCY AND NEW SUEZ CANAL PROJECT}

The maritime sector is composed of highly competitive businesses. This is because the industry has often faced governmental mandates for achieving regulatory compliance, including safety, security or environmental requirements. Meeting these requirements has been typically perceived as added costs that impede to compete in the sea trade marketplace. With applying the eco-efficiency concept on the New Suez Canal Project and the Suez logistics corridor project in order to make a trade-off between business and environment, a set of attributes can be applied for this purpose (Adams et al., 2009).

\section{BUSINESS APPROACHES}

The Suez logistics corridor and the New Canal projects must comply with their applicable environmental laws and regulations in order to avoid enforcement actions by the responsible government agencies. Targeted investors are looking forward to motivating 'greening' initiatives. Recently, 'green' and 'sustainability' issues have become essential requirements for improving maritime transport (IMO, 2014). On the other hand, there are three potential reasons that a business may invest in improving its environmental performance: 1) social license to operate, 2) corporate conscience, and/or 3) competitive advantage. The most important issue for any business established in the corridor is to avoid water or air pollution problems or congestion problems as this will affect the environment as well as the business itself.

\section{DRIVERS FOR ENVIRONMENTAL INITIATIVES}

The drivers for Suez Logistics Corridor investments in environmental performance are many and varied. On top of the list are regulatory compliance and courtordered activities where businesses, ports and logistics adding-value activities are forced to make investment to avoid further legal action. There are other drivers, motivations, and considerations as listed in Table 1.

\begin{tabular}{|c|c|c|}
\hline MOTIVES & \multicolumn{2}{|l|}{ DRIVERS } \\
\hline \multirow{2}{*}{$\begin{array}{c}\text { Regulatory } \\
\text { compliance } \\
\text { (1) }\end{array}$} & $\begin{array}{l}\text { International Marine and/or environmental } \\
\text { legislation }\end{array}$ & Regional environmental legislation \\
\hline & Local (e.g. provincial) environmental legislation & Self-regulation \\
\hline \multirow{4}{*}{$\begin{array}{l}\text { Response to } \\
\text { societal } \\
\text { pressures (and } \\
\text { enjoy resulting } \\
\text { direct economics } \\
\text { benefits) } \\
\text { (2) }\end{array}$} & Corporate and Social Responsibility & $\begin{array}{l}\text { Local communities concerns and } \\
\text { public relations }\end{array}$ \\
\hline & $\begin{array}{l}\text { Environment's protection and/or quality } \\
\text { improvement }\end{array}$ & $\begin{array}{l}\text { Assess environmental impact of } \\
\text { port's activities }\end{array}$ \\
\hline & $\begin{array}{l}\text { Economic Incentives (Tax exemption, subsidies, } \\
\text { capitalization, revenues) }\end{array}$ & $\begin{array}{l}\text { Insurance premium \& liabilities } \\
\text { reductions }\end{array}$ \\
\hline & $\begin{array}{l}\text { Environmental management } \\
\text { (e.g. Pollution Prevention) }\end{array}$ & Profit: Emissions trading market \\
\hline \multirow{2}{*}{$\begin{array}{l}\text { Development \& } \\
\text { Planning } \\
\text { (3) }\end{array}$} & Coastal zones planning & Port policy and planning \\
\hline & $\begin{array}{l}\text { Component of port's sustainable development } \\
\text { program }\end{array}$ & \\
\hline \multirow{3}{*}{$\begin{array}{l}\text { Operational } \\
\text { issues } \\
\text { (4) }\end{array}$} & Operational performance & Costs reduction and control \\
\hline & Health and safety issues & Labor relations \\
\hline & Processes standardization & $\begin{array}{l}\text { Environmental problem-solving } \\
\text { and remediation plan }\end{array}$ \\
\hline \multirow{5}{*}{$\begin{array}{l}\text { Gain competitive } \\
\text { advantage } \\
\text { (5) }\end{array}$} & Competition between regional ports & Corporate strategy \\
\hline & Short sea shipping promotion & New Markets \\
\hline & Create/Enhance/Promote "green logistics" & Collaborative logistics \\
\hline & $\begin{array}{l}\text { External business pressure } \\
\text { (e.g. Shipping lines, terminal operators) }\end{array}$ & Strategic alliances \\
\hline & Commercial and marketing interest & \\
\hline
\end{tabular}




\section{INCREASING PRESSURE AND MOTIVATIONS}

Port, Maritime and shipping industries have become targets for public environmental policy regulations (IMO, 2014). Proper management of water bodies and sediments, air emissions, waste reception facilities, and modal split of port related hinterland traffic are 'hot button' issues in today's port policy agendas. To a certain extent, ports are being pressured to respond to problems related to environmental harm resulting from shipping activities, whether moved by ships or trucks. Also, the rapid growth of cargo volumes over the years and expanding port infrastructure led to an increase in both environmental problems and societal pressures.

Figure 3. shows the overview of total sea pollution due to an increase in cargo volumes handled at seaports, worldwide.

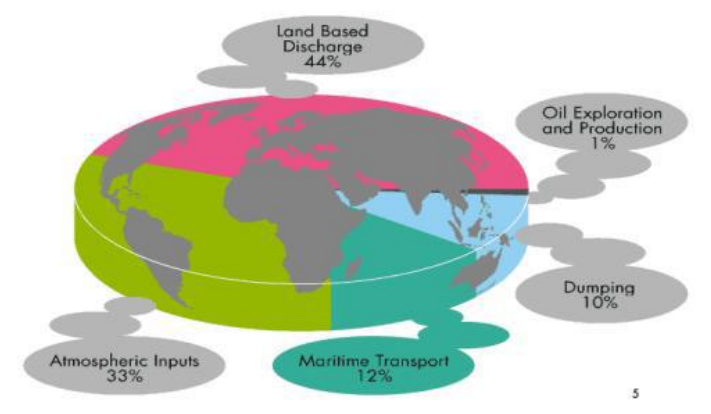

Fig .3. Overview of Total Sea Pollution Source: IMO, 2012

\section{SPILLOVER EFFECTS AND TIMELINES}

As an eco-efficiency dynamic, the 'green' practices create spillover effects. Once a business in the Suez region begins to address environmental matters, the interdependent nature of ecological and physical elements inevitably will lead towards ever-broader responses. Hence, green suppliers and transporters became a mandatory requirement to any business enterprise and supply chains become greener.

\section{RESULTS}

As discussed in Table 1, there are many drivers affecting the environmental performance in national mega projects. It is recommended in this paper to apply an Eco-Efficiency Analysis (EEA) that provides businesses and organizations with more fully- measured footprint of their projects or processes. This tool aims at evaluating the economic and environmental impacts of a product or process. It differs from other tools such as the Life Cycle Assessment (LCA) tool that eco-efficiency analyses evaluate both environmental burdens and economic costs, whereas LCA evaluate only environmental burdens. EEA works as follows:

- It provides managers with both environmental and economic data around a project.

- An EEA can accurately analyze those potential drivers in a project relying on the credible baseline data.

- From that baseline, an environmental footprint can be prioritized or cost reduction efforts.

- It helps to identify broader the optimization targets in a project.

- The level of detail and data provided is far beyond that available in a life cycle analysis and can be the basis for attaining higher sustainability goals.

As the methodology in this paper is Exploratory (inductive in nature) rather than Explanatory approach, this paper aims at understanding and finding the appropriate methodology that can be used by managers in such mega projects to measure the environmental performance. As further research in future, it is recommended to apply EEA tool in the Suez Canal Area Development Project when data will be available and accessible.

\section{CONCLUSION}

This research is trying to seek out an answer as to how any project can spot the preferred solution for balancing the business and environmental concerns, and how any project can enhance the trade-off between those two dimensions. Answering these two questions, the efficient frontier between the profitability and the environmental impact has been discussed.

Establishing such new national mega projects such as the New Suez Canal and the Suez Canal Area Development Project will certainly affect carrier and shipper market practices. Ports, transporters, 
investors, businesses and other players in these projects should be prepared to proactively address the environmental issues that are emerging, which may also have a potential impact on costs and carrier market practices.

Making a balance/trade-off between business and the environment has received little attention in the available literature so far. Hence, this research has discussed some attributes that can attain this goal using the eco-efficiency concept. These issues may have even greater impacts on both projects for doing global maritime business, particularly if dealt with reactively. On the other hand, if dealt with from an anticipatory perspective, there may be a possibility of improving a port's competitive position while reducing costs to shippers and carriers. Environmental issues can no longer be considered only as added costs but actively treated as business opportunities. As the purpose of this paper is limited to find the appropriate methodology for managing the environmental performance in national projects, Eco-Efficiency Analysis (EEA) is recommended to be applied in the future using Explanatory approach when the required data are available.

\section{REFERENCES}

[1] Adams, M., QUINONEZ, P., Pallis, A., and Wakeman, T. (2009) Environmental Issues in Port Competitiveness. Dalhousie University: Halifax.

[2] Bloemhof-Ruwaard, J.M., Krikk, H. and Van Wassenhove, L.N. (2004) OR Models for EcoEco Closed-Loop Supply Chain Optimization. Vol. 1, Springer, Berlin: Heiderberg.
[3] Huppes, G.and Ishikawa, M. A. (2005) Framework for Quantified Eco-efficiency Analysis. Journal of Industrial Ecology, Vol. 9(4), pp. 25-41.

[4] Krikke, H., Bloemhof-Ruwaard, J.M. and Van Wassenhove, L. N. (2003) Current Product and Closed Loop Supply Chain Design with an Application to Refrigerators. International Journal of Production Research, Vol. 41(16), pp.3689-3719.

[5] Quariguasi Frota Neto, J., Bloemhof-Ruwaard, J, Van Nunen, J.A.E.E. and Van Heck, E. (2008) Designing and evaluating sustainable logistics networks. International Journal of Production Economics, pp. 195-208.

[6] Quariguasi Frota Neto, J., Walther, G.,.Bloemhof, J., J.A.E.E Van Nunen and Spengler, T. (2007) Methodology for Assessing Eco-Efficiency in Logistics Networks ERIM, , pp. 1-37.

[7] Ministery of Planning and International Cooperation (June 2012) Strategic Framework for Economic and Social Development plan 2022

[8] IMO, (2014) A Concept of A Sustainable Maritime Transportation System. International Shipping Facts and Figures.

[9] IMO, (2012) Information Resources on Trade, Safety, Security, Environment. 